\title{
Second Annual Report on the Prairie Nest Records Scheme
}

The accumulation of basic biological data in the form of "nest records" is fundiamental to an understanding of the lives of birds. The annual breeding period, reproductive success, distribution of resident birds, correlation between breeding behaviour and climatic and environmental changes - these are some of the vital aspects of life history derived from nest records. In the two seasons of operation of the Nest Records Scheme more than 3000 nest record cards have been submitted. Within a few years there will be a great amount of information available for study. Already the files have proved useful as a guide to locating breeding birds. Dr. R. W. Storer, of the Univ. of Michigan, for example, who will be returning to Saskatchewan this summer to continue his studies of the comparative behaviour of grebes, will visit some of the colonies reported by our contributors. Breeding dates reported allow him to time his visits. It should be clear that every interested person has access to the information contained in these files. Direct inquiries to the Museum.

By the middle of January, 1960, forty-five contributors (for 1959) had returned 1696 cards. About 14,10 nests were recorded for 107 species of birds; in addition 14 colonies of six species were reported.

SPECIES LIST: Common Loon (1); Rednecked Grebe (2); Horned Grebe (9); Eared Grebe ( $2+$ colony 227 nests); Western Grebe (colony 16 nests); Pied-billed Grebe (2); Mallard (72); Gadwall (1); Pintail (11); Blue-winged Teal (1); American Widgeon (10); Shoveler (2); Redhead (1); Canvasback (4); Lesser Scaup (2); Common Goldeneye (1); Turkey Vulture (1); Sharp-shinned Sawk (6-; Cooper's Hawk (13); Red-tailed Hawk (41); Broad-winged Hawk (1); Swainson's Hawk (10); Ferruginous Hawk (7); Golden Eagle (4); Marsh Hawk (18); Prairie Falcon (14); Pigeon Hawk (11); Sparrow Hawk (5); Ruffed Grouse (3); Sharp-tailed Grouse (5); Sage Grouse (2); Gray Partridge (2); Sora (3); American Coot (9); Piping Plover (1); Killdeer (34); Spotted Sandpiper (2); Willet (2); Marbled Godwit (3); American Avocet (20); Wilson's Phalarope (3); Forster's Tern (3); Common Tern (3); Black Tern (7); Mourning Dove (49); Great Horned Owl ( 55 ); Burrowing Owl (6); Long-eared Owl (15); Short-eared Owl (3); Common Nighthawk (3); Yellow-shafted Flicker (21); Yellowbellied Sapsucker (3); Hairy Woodpecker (2); Downy Woodpecker (4); Eastern Kingbird
(36); Western Kingbird (6); Great Crested Flycatcher (1); Eastern Phoebe (18); Say's Phoebe (3); Traill's Flycatcher (1); Least Flycatcher (5); Western Wood Pewee (1); Horned Lark (51); Tree Swallow (18); Bank Swallow $(3+5$ colonies of 5 to 36 nests); Barn Swallow (53); Cliff Swallow $(10+3$ colonies of 50 to 570 nests); Purple Martin ( $3+$ colony of 3 nests); Black-billed Magpie (63); Common Crow (67); Black-capped Chickadee (1); White-breasted Nuthatch (1); House Wren (34); Rock Wren (1); Catbird (19); Brown Thrasher (8); Robin (66); Swainson's Thrush (1); Veery (6); Mountain Bluebird (10); Sprague's Pipit (1); Cedar Waxwing (18); Loggerhead Shrike (11); Starling (32); Red-eyed Vireo (1); Warbling Vireo (9); Tennessee Warbler (1); Yellow Warbler (18); Ovenbird (1); American Redstart (1); House Sparrow (10); Bobolink (3); Western Meadowlark (17); Yellow-headed Blackbird ( $6+2$ colonies); Redwinged Blackbind $(117+$ colony $)$; Baltimore Oriole (7); Brewer's Blackbird (30); Common Grackle (16); Rose-breasted Grosbeak (1); American Groldfinch (5); Lark Bunting (1); Savannah Sparrow (8); Vesper Sparrow (18); Lark Sparrow (1); Chipping Sparrow (8); Claycolored Sparrow (51); Song Sparrow (7); Chestnut-collared Longspur (10).

CONTRIBUTORS 1959 (especially note worthy numbers of cards indicated): S. Alberts, W. Anaka (84), P. L. Beckie, J. B. Belcher, M. Belcher, J. Briggs, D. Buckle, J. D. Chandler, R. T. Cowell, J. Dew, E. G. Evans, G. Fletcher, G. Foster, E. L. Fox and R. Fox (75), G. A. Fox (129). R. Fyfe, D. Gilroy, J. Gunn, D. Hatch (131 from Man.), W. Horseman (155), A. J. Hruska, E. K. Hubband, S. O. Jordheim, D. Karasiuk, R. Klimack, E. Kuyt, F. W. Lahrman, J. Lane. K. Leier, L. M. Lohr, H. S. McArton, R. W. Nero, R. O'Connor, R. Ostoforoff, Mr. and Mrs. K. D. Paton, Sask. Falconry Association

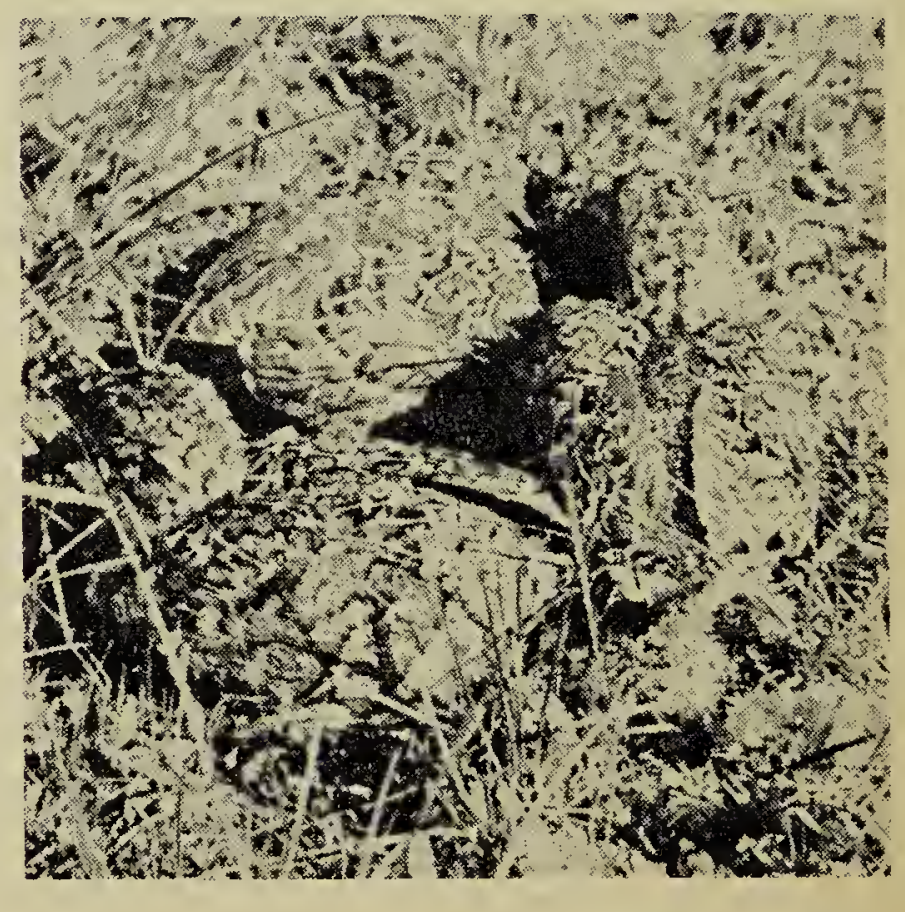

Photo by $R$. J. Fyfe

Three Sage Grouse chicks, Killdeer badlands June 28, 1959. 
(97), S. Sealey (181), W. Shudzik, G. E. Smith, S. Waycheshen, F. A. Wilson, S. Zazelenchuk (65).

Note: Records are filed at the S.M.N.H. Members of the Museum staff have handled the 1959 cards and prepared this summary.Ed.)

A few contributors included general remarks or a summary of the 1959 season. For example, W. Anaka of Spirit Lake, Sask., noted a "sharp decrease of all species requiring wet habitat-ducks, coots, rails, shorebirds, blackbirds, etc. Several species were absent altogether, and only 15$20 \%$ of the 1958 total of breering pairs were present in 1959 Other species not directly affected by the dry conditions appeared to have a normal year. Increases were noted in the Red-tailed Hawk and the Bobolink although only one nest of the latter was located. The Black-billed Magpie had excellent fledgling success; the Common Crow showed marked increase of breeding pairs, but low success ratio." We urge others to submit this additional information whenever possible.

You are reminded that the P.N.R.S. is collecting information for the three prairie provinces and the Northwest Territories. Cards are being sent to all 1959 contributors; others who wish to record nest data should write for cards. Write to Prairie Nest Records Scheme, c/o Saskatchewan Museum of ${ }^{\circ}$ atural History, Regina. Sask.

\section{Support Our Special Publications}

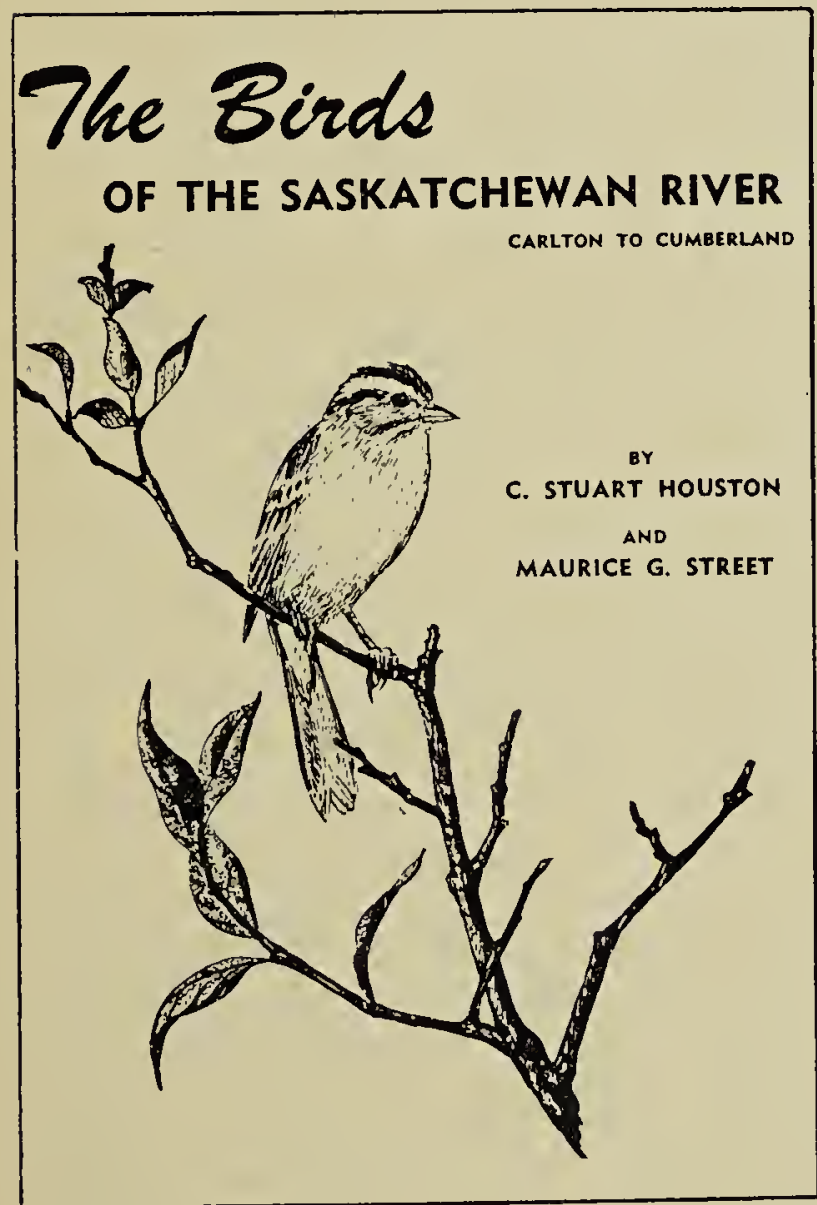

The Birds of the Saskatchewan River, Carlton to Cumberland (1959) is the second and most recent publioation in the S.N.H.S.'s series reporting natural history studies being carried out by its members. The price of the 205-page bulletin on the birds of Central Sask. is $\$ 1.50$. -a splendid example of the type of contribution that amateurs can make to ornithology.-O. E. Devitt in the F.O.N. Bulletin.

-what a pleasure to take up The Birds of the Saskatchewan River and find it to be not only an accurate check list, but a thoroughly fascinating historical account.-R. W. Sutton in The Beaver.

-Dr. Houston's account of the history of previous work on the birds of the Saskatchewan River area is outstanding.-J. L. Baillie in Canadian Audubon.

- the authors are to be highly commended for their initiative and thoroughness in producing this scholarly work which doubtless will retain its usefulness for a long time, to come.-W. E. Godfrey in The Blue Jay.

\section{ORDER SPECIAL PUBLICATIONS}

\#1. Guide to Sask. Mammals. ..50

\#2. Birds of the Sask. River. \$1.50 from

Margaret Belcher, Secretary, Regina College, Regina. 